\title{
DOWNSCALING PLANETARY BOUNDARIES TO THE NATIONAL LEVEL: A REVIEW OF METHODS AND INDICATORS
}

\author{
ANETA PARSONSOVÁ \\ Department of Development and Environmental Studies, Faculty of Science, Palacky \\ University, TR 17 listopadu 12, 77146 Olomouc, Czech Republic \\ Corresponding author: aneta.parsonsova@gmail.com
}

Received: $23^{\text {th }}$ May 2019, Accepted: $9^{\text {th }}$ June 2021

\begin{abstract}
The practical implementation of the planetary boundaries' (PB) conceptual implications is a challenge from the perspective of both global and national governance. (Schmidt, 2013; Biermann \& Kim, 2020) This paper reviews the methods and indicators used in subsequent studies which focus on downscaling the PB concept to the national level. The conclusions confirm significant progress in identifying appropriate national indicators; however, also point at the need for further research to (1) develop a complex downscaling methodology; (2) consider additional variables to ensure just and equitable allocation principles; and (3) mainstream the PB into national policies.
\end{abstract}

Keywords: Planetary Boundaries, environmental limits, sustainability

The concept of planetary boundaries provided the first comprehensive and science-based ceiling for the environmental pillar of global sustainable development. It was first published in 2009 (Rockström et al.), updated in 2015 (Steffen et al.) and widely cited in both academic literature and policy documents. The nine key biophysical processes identified (climate change, ocean acidification, stratospheric ozone depletion, freshwater use, land-system change, biosphere integrity, biochemical flows, atmospheric aerosol loading, novel entities) and their boundaries define the "safe operating space for humanity" in which anthropogenic factors do not cause abrupt and non-linear global environmental changes. (Rockström et al., 2009; Steffen et al., 2015)

Although indirectly, the concept influenced the current global sustainable development (SD) agenda adopted by the United Nations (UN) in 2015. All nine planetary processes are addressed at some level within the global Sustainable Development Goals (SDGs) or their targets. (Hoff et al., 2017; Lucas \& Wilting, 2018) A deeper understanding of the links between the two concepts at the global level was provided by a report for the Club of Rome published in 2018. The study introduced the Earth3 model, which connects socioeconomic and biophysical processes key to sustainable development. (Randers et al., 2018) The main responsibility for achieving the SDGs by 2030 lies with the UN Member States and their governments. (UN, 2015) As a result, the concept of planetary boundaries has its current significance in the national context as well. However, further research is needed to better understand the application and use of $\mathrm{PB}$ at the regional and national levels. 

Indicators

The first study on the relation between PB and national environmental targets was applied to Sweden. (Nykvist et al., 2013) The authors identified appropriate indicators related to selected PB which could be assessed at the global and national level. They also distinguished between the territorial (production-based) and footprint (consumption-based) performance of countries (Figure 1), and addressed the equity issue related to the rights to development by considering the performance per capita. The per capita performance has lately been identified as the most common sharing principle in terms of the application of the distributive justice theory to the "safe operating space". (Ryberg et al., 2020).

Fig. 1: Footprint and territorial indicators (adapted from Dao et al., 2015)

\begin{tabular}{|c|c|c|c|c|}
\hline & & \multicolumn{2}{|c|}{ Consumption } & \\
\hline & & National & Abroad & \\
\hline \multirow{2}{*}{ 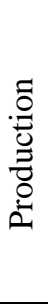 } & National & $\begin{array}{l}\text { Internal environmental } \\
\text { impact of production } \\
\text { for consumption }\end{array}$ & $\begin{array}{l}\text { Internal environmental } \\
\text { impact of production for } \\
\text { foreign consumption } \\
\text { (export) }\end{array}$ & $\begin{array}{l}\text { Territorial } \\
\text { indicators }\end{array}$ \\
\hline & Abroad & \multirow{2}{*}{$\begin{array}{l}\text { External } \\
\text { environmental impact } \\
\text { of production for } \\
\text { consumption (import) } \\
\text { Footprint } \\
\text { indicators }\end{array}$} & $\begin{array}{l}\text { External environmental } \\
\text { impact of production for } \\
\text { foreign consumption }\end{array}$ & \\
\hline & & & & \\
\hline
\end{tabular}

Most approaches favour the use of consumption-based indicators as a more accurate measurement of countries' environmental pressures. Hoekstra \& Wiedmann (2014) argued for the complementarity of the environmental footprints and PB concept. Fang et al. (2015) explored the relationship between the footprint and boundary indicators further and proposed a footprint-boundary environmental sustainability assessment. However, the consumption-based data are often missing at the national level and territorial indicators may still have their relevance for national assessments of the PB. (Hongwei Huang et al., 2020)

Some studies attempted to incorporate the PB concept to the current three-pillar conception of SD and broaden it with its socio-economic dimension (e.g. Raworth, 2012). Cole et al. (2014) introduced a "barometer" combining 20 environmental boundaries and social deprivation indicators and applied it to South Africa with the objective to identify priority areas for national policy. Another important study compared the boundary metrics to the footprint metrics in carbon, water and land use PB and applied the methodology to a dataset of 28 countries. The sustainability gap between the safe performance and performance exceeding the critical threshold was measured by the environmental sustainability ratio (ESR). The ESR was counted as the ratio between the footprint and relevant PB. (Fang et al., 2015)

Significant progress in terms of allowing for a fairer distribution of the remaining global environmental budgets based on the PB among countries and individuals was made on a case study of Switzerland (Dao et al., 2018). The authors selected indicators for five of the PB and considered the historical responsibility of the footprints (e.g. past GHG emissions in accounting for the climate change $\mathrm{PB})$. The indicators selected for the assessment were classified into two categories: (1) state indicators (e. g. $\mathrm{CO}_{2}$ concentrations), and (2) pressure 
indicators (e.g. $\mathrm{CO}_{2}$ emissions) based on their position in the DPSIR causal chain (see EEA, 2005). Similar methodology, considering also production-based indicators, was applied to a larger dataset of 202 countries and the climate change PB by Hickel (2020).

Several other studies have focused rather on regional and sub-regional assessments. For instance, a study evaluated the implementation of the EU Environment Action Programme titled "Living Well, within the Limits of our Planet" by assessing the impact of European consumption on the transgression of PB. (Hoff et al., 2014) Recently, the European Environment Agency published a comprehensive update including a wider range of EU environmental policies and a case study of Switzerland. (EEA and FOEN, 2020) Dearing et al. (2014) applied an integrated approach involving biophysical and social dimensions of SD to two low-income communities in China. Other studies focused only on selected PB and countries, e.g. the biochemical cycle of nitrogen in Ethiopia and Finland (Kahiluoto et al., 2015) or climate change in the Czech Republic (Parsonsová \& Machar, 2021). The later study also provided a preliminary assessment of the use of additional variables expanding the "equal share per capita" principle.

A first attempt to establish comprehensive operationalization of $\mathrm{PB}$ and their downscaling into national goals was a three-step approach including gradual transformation of the global biophysical, socioeconomic and ethical dimensions of PB into indicators relevant on the national level. For each of the dimensions, a set of analytical and integration tools was designed and their interlinkages were considered. (Häyhäa et al., 2016) However, these analytical and integration tools serve only as examples, not as a systemic methodology for setting national goals and priorities.

As mentioned earlier, the process of downscaling PB into fair and equitable national shares requires the application of a distributional mechanism. A paper published in 2014 compared over 40 studies proposing various sharing-schemes for the remaining emissions allowance and proposed to classify the allocation principles into four categories: (1) responsibility (concerns historical contributions to global emissions or warming); (2) capability (also called 'capacity' or 'ability to pay for mitigation'); (3) equality (equal rights per person, immediately or over time); and (4) cost effectiveness. (Höhne et al., 2013) Although subsequent reports (e. g. Sabag Munoz \& Gladek, 2017; EEA \& FOEN, 2020) introduced extended allocation principles categories, the majority of earlier cited studies on PB fit into the original 4-tier classification.

In order to assess national PB, the above-described distribution mechanisms have to be applied to appropriate control variables. The global control variables used in the original PB studies (Rockström et al., 2009; Steffen et al., 2015) are not relevant for the computation of national PB as they often cannot be attributed to individual countries. The indicators used in key national and regional case studies (Sweden, Switzerland, Taiwan and Europe) are summarized in Table 1. The table shows that appropriate control variables which could be downscaled to the national level were in various studies already identified for six out of the seven operationalized PB. However, no national study including all six PB has yet been carried out. 
Parsonsová A.: Downscaling Planetary Boundaries to the National Level: A Review of Methods and Indicators

Table 1: Control variables for selected PB used in key national and regional case studies

\begin{tabular}{|c|c|c|c|c|c|}
\hline \multirow{2}{*}{$\begin{array}{l}\text { Planetary } \\
\text { Boundary }\end{array}$} & \multicolumn{5}{|c|}{ Control variable (global limit) } \\
\hline & $\begin{array}{l}\text { Steffen et al. } \\
(2015)\end{array}$ & $\begin{array}{l}\text { Nykvist et al. } \\
(2013)\end{array}$ & $\begin{array}{lll}\begin{array}{l}\text { Dao } \\
(2018)\end{array} & \text { et } & \text { al. } \\
\end{array}$ & $\begin{array}{l}\text { EEA and } \\
\text { FOEN (2020) }\end{array}$ & $\begin{array}{l}\text { Hongwei Huang } \\
\text { et al. }(2020)\end{array}$ \\
\hline \multirow[t]{2}{*}{$\begin{array}{l}\text { Climate } \\
\text { change }\end{array}$} & $\begin{array}{l}\text { Atmospheric } \mathrm{CO}_{2} \\
\text { concentration, } \\
\text { ppm }(350 \mathrm{ppm} \\
\left.\mathrm{CO}_{2}\right)\end{array}$ & \multirow[t]{2}{*}{$\begin{array}{l}\text { Per capita } \mathrm{CO}_{2} \\
\text { emissions }\end{array}$} & \multirow{2}{*}{$\begin{array}{l}\text { Remaining } \\
\text { cumulative } \\
\text { GHG emissions } \\
\text { (including land } \\
\text { cover changes) }\end{array}$} & \multirow[t]{2}{*}{-} & \multirow[t]{2}{*}{$\begin{array}{l}\text { Cumulative and } \\
\text { annual GHG } \\
\text { emissions, } \mathrm{CO}_{2} \text {, } \\
\mathrm{CH}_{4}, \mathrm{~N}_{2} \mathrm{O}\end{array}$} \\
\hline & $\begin{array}{l}\text { Energy imbalance } \\
\text { at } \\
\text { top-of-atmosphere, } \\
\mathrm{W} / \mathrm{m}^{-2}(+1.0 \mathrm{~W} \\
\left.\mathrm{m}^{-2}\right)\end{array}$ & & & & \\
\hline $\begin{array}{l}\text { Ocean } \\
\text { acidification }\end{array}$ & $\begin{array}{l}\text { Carbonate ion } \\
\text { concentration, } \\
\text { average global } \\
\text { surface ocean } \\
\text { saturation state } \\
\text { with respect to } \\
\text { aragonite }(\geq 80 \% \\
\text { of the } \\
\text { pre-industrial } \\
\text { level) }\end{array}$ & - & $\begin{array}{l}\text { Remaining } \\
\text { cumulative } \mathrm{CO}_{2} \\
\text { emissions from } \\
\text { human activities } \\
\text { to maintain an } \\
\text { acceptable } \\
\text { calcium } \\
\text { carbonate } \\
\text { saturation state } \\
\Omega\end{array}$ & - & $\begin{array}{l}\text { Cumulative and } \\
\text { annual } \mathrm{CO}_{2} \\
\text { emissions }\end{array}$ \\
\hline \multirow[t]{2}{*}{$\begin{array}{l}\text { Land-system } \\
\text { change }\end{array}$} & $\begin{array}{l}\text { Area of } \\
\text { forested land as } \% \\
\text { of original forest } \\
\text { cover }(75 \%)\end{array}$ & $\begin{array}{l}\text { Safe amount of } \\
\text { ice-free land that } \\
\text { humans can } \\
\text { convert globally } \\
\text { divided by world } \\
\text { population }\end{array}$ & \multirow{2}{*}{$\begin{array}{l}\text { Surface of } \\
\text { anthropised } \\
\text { land, i.e. } \\
\text { agricultural and } \\
\text { urbanised } \\
\text { (sealed) land, as } \\
\text { percentage of } \\
\text { ice-free land } \\
\text { (water bodies } \\
\text { excluded) }\end{array}$} & \multirow[t]{2}{*}{$\begin{array}{l}\text { Area of } \\
\text { antropised } \\
\text { land }\end{array}$} & \multirow[t]{2}{*}{$\begin{array}{l}\text { Forest cover; } \\
\text { anthropized land } \\
\text { from potential } \\
\text { forest cover }\end{array}$} \\
\hline & & $\begin{array}{l}\text { Limiting cropland } \\
\text { to } 15 \% \text { of } \\
\text { nationally } \\
\text { available land }\end{array}$ & & & \\
\hline \multirow[t]{2}{*}{$\begin{array}{l}\text { Freshwater } \\
\text { use }\end{array}$} & \multirow[t]{2}{*}{$\begin{array}{l}\text { Maximum } \\
\text { amount of } \\
\text { consumptive blue } \\
\text { water use ( } 4000 \\
\mathrm{~km}^{3} \mathrm{yr}^{-1} \text { ) }\end{array}$} & $\begin{array}{l}40 \% \text { of total } \\
\text { global } \\
\text { renewable water } \\
\text { resources divided } \\
\text { by world } \\
\text { population } \\
\end{array}$ & \multirow[t]{2}{*}{-} & \multirow[t]{2}{*}{$\begin{array}{l}\text { Maximum } \\
\text { amount of } \\
\text { consumptive } \\
\text { blue water use } \\
\text { per year }\end{array}$} & \multirow[t]{2}{*}{$\begin{array}{l}\text { Annual and } \\
\text { monthly } \\
\text { withdrawals; } \\
\text { spatial monthly } \\
\text { withdrawal }\end{array}$} \\
\hline & & $\begin{array}{l}\text { Maximum } \\
\text { withdrawal of } \\
40 \% \text { of nationally } \\
\text { available } \\
\text { freshwater }\end{array}$ & & & \\
\hline \multirow[t]{2}{*}{$\begin{array}{l}\text { Biosphere } \\
\text { integrity }\end{array}$} & $\begin{array}{l}\text { Extinction rate }(< \\
10 \mathrm{E} / \mathrm{MSY})\end{array}$ & \multirow[t]{2}{*}{-} & \multirow{2}{*}{$\begin{array}{l}\text { Potential } \\
\text { damages to } \\
\text { biodiversity per } \\
\text { land cover types } \\
\text { accounting for } \\
\text { the level of } \\
\text { biodiversity per } \\
\text { biome }\end{array}$} & \multirow[t]{2}{*}{-} & \multirow[t]{2}{*}{-} \\
\hline & \begin{tabular}{l}
\multicolumn{3}{l}{ Biodiversity } \\
Intactness Index \\
(Maintain BII at \\
$90 \%$
\end{tabular} & & & & \\
\hline
\end{tabular}


Journal of Landscape Ecology (2021), Vol: 14 / No. 2

\begin{tabular}{|c|c|c|c|c|c|}
\hline \multirow[t]{2}{*}{$\begin{array}{l}\text { Biochemical } \\
\text { flows }\end{array}$} & $\begin{array}{l}\text { Industrial } \\
\text { and intentional } \\
\text { biological fixation } \\
\text { of } \mathrm{N}\left(62 \mathrm{Tg} \mathrm{N} \mathrm{yr}^{-1}\right)\end{array}$ & $\begin{array}{l}\text { Per capita net } \\
\text { territorial use of } \mathrm{N}\end{array}$ & $\begin{array}{l}\text { Loss of reactive } \\
\mathrm{N} \text { into the } \\
\text { environment }\end{array}$ & $\begin{array}{l}\text { Loss of } \\
\text { nitrogen from } \\
\text { agriculture per } \\
\text { year }\end{array}$ & $\mathrm{N}$ fertilizer used \\
\hline & $\begin{array}{l}\text { P flow } \\
\text { from freshwater } \\
\text { systems into the } \\
\text { ocean (11 Tg P } \\
\left.\mathrm{yr}^{-1}\right)\end{array}$ & - & $\begin{array}{l}\text { Use of fertilizers } \\
\text { with Phosphorus }\end{array}$ & $\begin{array}{l}\text { Loss of } \\
\text { phosphorus } \\
\text { from } \\
\text { agriculture } \\
\text { and waste } \\
\text { water per year }\end{array}$ & $\begin{array}{l}\text { Total } \mathrm{P} \text { flow } \\
\text { from rivers to } \\
\text { oceans }\end{array}$ \\
\hline
\end{tabular}

Current national sustainable development reporting mechanisms are mainly linked to the global SDGs monitoring framework and complemented with national and regional data. The global framework consists of 231 SDGs indicators. Considering the relatively high number of data series in the set, data gaps and incoherent assessments of various international organisations and think-tanks, the SDGs reports could lead to inconsistent and ambiguous results. (Janoušková et al., 2018, Lafortune et al., 2020) Furthermore, some of the Goals could contradict each other, if current trends are maintained (e.g. SDG 8 Decent Work and Economic Growth and SDG 13 Climate Action). This could lead to falsely positive results of SD reports, as countries may seem to make progress in achieving SDGs despite their effects on global biophysical processes which contribute to the transgression of the planetary boundaries. The application of the PB concept on the national level is therefore a useful instrument for understanding the transboundary impact of national environmental performance.

At the global level, four out of the seven quantified PB were already transgressed by 2015 (climate change, biosphere integrity, biochemical flows and land-system change). The most recent update of the study identified two core PB (climate change and biosphere integrity), and four PB with strong regional operation scales (biosphere integrity, biogeochemical flows, land-system change, freshwater use, and atmospheric aerosol loading). Transgression of any of the proposed regional boundaries affects the Earth system at the global level. (Steffen et al., 2015) Similarly, the national case studies clearly show that some of the PB have already been transgressed at the national level (e.g. Nykvist et al., 2013; Dao et al., 2018; Hongwei Huang et al., 2020; Parsonsová \& Machar, 2021) and the aggregate anthropogenic environmental pressures of individual countries may cause non-linear changes in the Earth-system. As a consequence of that, the global conditions are moving away from the relatively stable Holocene-like state with limited capacity to accommodate the development needs of all individuals. (Steffen et al., 2015)

The studies reviewed in this paper provided a satisfactory knowledge basis for selecting PB indicators applicable at the national level. However, further research is needed in order to establish a comprehensive downscaling methodology. Additional variables have to be incorporated in the allocation models to ensure fair and equitable distribution principles in regard to the needs of all individuals now and in the future, and their ability to pay for mitigation. National context and nationally- or regionally-specific environmental ceilings have to be considered in the models. Furthermore, additional instruments should be developed to allow for mainstreaming the PB into national environmental policies.

\section{CONFLICTS OF INTEREST}

The authors declare no conflict of interest. 


\section{REFERENCES}

Biermann, F., Kim, R. E. (2020). The Boundaries of the Planetary Boundary Framework: A Critical Appraisal of Approaches to Define a "Safe Operating Space" for Humanity. Annual Review of Environment and Resources. 45:497-521. Retrieved February 15, 2021, from https://doi.org/10.1146/annurev-environ-012320- 080337.

Cole, M., Bailey, R., New, M. (2014). Tracking sustainable development with a national barometer for South Africa using a downscaled "safe and just space" framework. Proc. Natl. Acad. Sci. USA, 111, E4399-E4408.

Dao, H., Peduzzi, P., Friot, D. (2018). National environmental limits and footprints based on the Planetary Boundaries framework: The case of Switzerland. Glob. Environ. Change, 52, 49-57.

Dearing, J.A., Wang, R., Zhang, K., Dyke, J.G., Haberl, H., Hossain, M.S., Langdon, P.G., Lenton, T.M., Raworth, K., Brown, S., et. al. (2014). Safe and just operating spaces for regional social-ecological systems. Glob. Environ. Change, 28, 227-238.

European Environment Agency (EEA), Federal Office for the Environment (FOEN) (2020). Is Europe living within the limits of our planet? An assessment of Europe's environmental footprints in relation to planetary boundaries 2020, ISBN 978-92-9480-215-6, doi:10.2800/890673.

Fang, K., Heijungs, R., De Snoo, G.R. (2015). Understanding the complementary linkages between environmental footprints and planetary boundaries in a footprint-boundary environmental sustainability assessment framework. Ecol. Econ., 114, 218-226.

European Environment Agency (EEA) (2005). EEA core set of indicators - Guide, EEA Technical report, No 1/2005, ISSN 1725-2237, Luxembourg: Office for Official Publications of the European Communities, $38 \mathrm{pp}$.

Häyhä, T., Lucas, P., van Vuuren, D., Cornell, S.E., Hoff, H. (2016). From Planetary Boundaries to national fair shares of the global safe operating space - How can the scales be bridged? Glob. Environ. Change, 40, 60-72.

Hickel, J. (2020). Quantifying national responsibility for climate breakdown: An equality-based attribution approach for carbon dioxide emissions in excess of the planetary boundary. Lancet Planet Health, 4, e399-e404.

Hoekstra, A. Y., Wiedmann, T. O. (2014). Humanity's unsustainable environmental footprint. Science 344 (6188), 1114-1117.

Hoff, H., Alva, L.I. (2017). How the Planetary Boundaries Framework can Support National Implementation of the 2030 Agenda; Stockholm Environment Institute: Stockholm, Sweden. Retrieved February 15, 2021, from https://mediamanager.sei.org/documents/Publications/ SEI-2017-PB-Hoff-HowthePlanetary.pdf

Hoff, H., Nykvist, B., Carson, M. (2014). Living Well, within the Limits of Our Planet? Measuring Europe's Growing External Footprint. SEI Working Paper 2014-05, Stockholm Environment Institute. Retrieved February 15, 2021, from https://www.sei.org/publications/living-well-within-the-limits-of-our-planet-measuring-eur opes-growing-external-footprint.

Höhne, N., den Elzen, M., Escalante, D. (2013). Regional GHG reduction targets based on effort sharing: a comparison of studies, Climate Policy 14(1), pp. 122-147; doi: 10.1080/14693062.2014.849452. 
Hongwei Huang, L., H. Hu, A., Kuo C-H. (2020). Planetary boundary downscaling for absolute environmental sustainability assessment - Case study of Taiwan, Ecological Indicators, Volume 114, 106339, ISSN 1470-160X, https://doi.org/10.1016 /j.ecolind.2020.106339.

Janoušková, S., Hák, T., Moldan, B. (2018). Global SDGs Assessments: Helping or Confusing Indicators? Sustainability, 10, 1540.

Kahiluoto, H., Kuisma, M., Kuokkanen, A., Mikkilä, M., Linnanen, L. (2015). Local and social facets of planetary boundaries: Right to nutrients. Environ. Res. Lett., 10, 104013.

Lafortune, G., Fuller, G., Schmidt-Traub, G., Kroll, C. (2020). How Is Progress towards the Sustainable Development Goals Measured? Comparing Four Approaches for the EU. Sustainability, 12, 7675.

Lucas, P. L., Wilting, H. C. (2018). Using planetary boundaries to support national implementation of environment-related Sustainable Development Goals, PBL Netherlands Environmental Assessment Agency, The Hague, PBL publication number: 2748.

Nykvist, B., Persson, Å., Moberg, F., Persson, L., Cornell, S., Rockström, J. (2013). National Environmental Performance on Planetary Boundaries: A Study for the Swedish Environmental Protection Agency, Report 6576, Naturvårdsverket. p. 122. ISBN 978-91-620-6576-8.

Parsonsová, A., Machar, I. (2021). National Limits of Sustainability: The Czech Republic's CO2 Emissions in the Perspective of Planetary Boundaries. Sustainability, 13, 2164. https://doi.org/10.3390/su13042164.

Raworth, K. (2012). Living in the doughnut. Nature Climate Change 2(4): 225-226.

Rockström, J., Steffen, W., Noone, K., Persson, Å., Chapin, F.S., Lambin, E.F., Lenton, T.M., Scheffer, M., Folke, C., Schellnhuber, H.J., et.al.. (2009). A safe operating space for humanity. Nature, 461, 472-475.

Ryberg, M.W., Andersen, M.M., Owsianiak, M., Hauschild, M.Z. (2020). Downscaling the planetary boundaries in absolute environmental sustainability assessments - A review. $J$. Clean. Prod., 276, 123287.

Sabag Munoz, O., Gladek, E. (2017). One planet approaches: methodology mapping and pathways foreward, report commissioned by WWF and IUCN, Retrieved February 15, 2021, from https://www.metabolic.nl/publications/one-planet-approaches-methodology-mappingand-pathways-forward/.

Schmidt, F. (2013). Governing planetary boundaries: Limiting or enabling conditions for transitions towards sustainability? In Meuleman, L., ed. : Transgovernance Advancing Sustainability Governance (pp. 215-34). Berlin: Springer.

Steffen, W., Richardson, K., Rockström, J., Cornell, S.E., Fetzer, I., Bennett, E.M., Biggs, R., Carpenter, S.R., de Vries, W., de Wit, C.A.. et.al.. (2015). Planetary boundaries: Guiding human development on a changing planet. Science, 347, 1259855.

United Nations (UN) (2015). Transforming our world: The 2030 Agenda for Sustainable Development, UN General Assambly, 2015, A/RES/70/1. Retrieved February 15, 2021, from: https://www.un.org/ga/search/view_doc.asp?symbol=A/RES/70/1\&Lang=E. 